\author{
MARTA Boguś \\ Uniwersytet Pedagogiczny w Krakowie, Polska \\ Pedagogical University of Cracow, Poland \\ SŁAWOMIR DOROCKI \\ Uniwersytet Pedagogiczny w Krakowie, Polska \\ Pedagogical University of Cracow, Poland
}

\title{
Międzynarodowe korporacje biotechnologiczne i farmaceutyczne na świecie
}

\section{International Biotechnological and Pharmaceutical Corporations in the World}

\begin{abstract}
Streszczenie: Współcześnie przemysł life science (w tym biotechnologiczny i farmaceutyczny - B\&F) uznawany jest za jeden z najważniejszych i najszybciej rozwijających się sektorów gospodarki zaawansowanych technologii. Przemysł ten jest ważnym czynnikiem rozwoju społeczno-gospodarczego poszczególnych krajów oraz regionów i w znaczący sposób wpływa na kształtowanie się gospodarki opartej na wiedzy. Szczególną rolę $w$ kreowaniu rozwoju gospodarczego odgrywają wielkie korporacje międzynarodowe, posiadające bogate zaplecze naukowe i kapitał. Korporacje działające $w$ tym sektorze gospodarki zmuszone są do podejmowania ciągłych działań innowacyjnych, co związane jest z szybkimi zmianami technologicznymi, a tym samym z dużym ryzykiem inwestycyjnym. Przedmiotem przeprowadzonych badań są transnarodowe korporacje biotechnologiczne i farmaceutyczne wyróżnione spośród 2000 największych korporacji różnych sektorów gospodarczych magazynu „Forbes”. Celem badań jest określenie prawidłowości przemian, jakie zachodziły w układach przestrzennych oraz w potencjale ekonomicznym transnarodowych korporacji biotechnologicznych i farmaceutycznych. Współcześnie można zaobserwować wzrost znaczenia tych podmiotów wśród największych korporacji światowych. Szczególnie szybko rozwija się przemysł biotechnologiczny (w tym biotechnologia biała), co jest spowodowane m.in. starzeniem się społeczeństwa, chorobami cywilizacyjnymi, wzrostem gospodarczym $\mathrm{w}$ krajach rozwijających się oraz zauważalną akceleracją rozwoju nowych technologii. Jako główne rejony rozwoju biotechnologii i farmacji podaje się kraje wysoko rozwinięte (np. USA, kraje Europy Zachodniej, Japonię). Jednak w ostatnich latach można zauważyć nasilający się proces delokalizacji przemysłu (w tym głównie w aspekcie produkcji i badań klinicznych). Proces delokalizacji sektora life science powiązany jest również z powstawaniem nowych rynków zbytu (np. Azja, Ameryka Południowa) i poszukiwaniem przez korporacje regionów proinwestycyjnych (np. Chiny, Indie). Jednakże spośród wszystkich czynników najważniejsza dla rozwoju biotechnologii sektorów life science jest infrastruktura B\&R, wysokiej jakości kapitał ludzki i czynniki infrastrukturalne (w tym odpowiednie normy etyczne i prawne).
\end{abstract}

Abstract: Contemporary, life science (including biotechnology and pharmacy) are regarded as one of the most significant and the fastest developing sectors of innovative (knowledge-based) economy and as the most important factors of socio-economic development. Biotechnological and pharmaceutical corporations are located mainly in the proximity to the world-class universities, providing access to a highly skilled workforce and research infrastructure and it is associated with a high risk investment resulting from rapid technological changes. The subject of the conducted research are international corporations selected from the list of 2000 biggest corporations in the world of the Forbes Magazine. The aim of the research is to determine the location and economical potential changes of the international biotechnology and pharmaceutical corporations. Nowadays, the importance of biotechnological and pharmaceutical corporations is growing. 
Biotechnology develops rapidly because of the aging of the society, civilisation illnesses, growing economies. The main regions famous for developing biotechnological and pharmaceutical corporations are highly developed countries such as the USA, Western European countries, Japan. However, the relocation of the industry is noticeable (location of production and clinical trials), searching for new markets and more friendly legal policy (China, India). Research and Development infrastructure, highly developed human capital and infrastructural factors (including ethical and legal ones) are the main factors of the development of biotechnology.

Słowa kluczowe: biotechnologia; farmacja; korporacje; life science

Keywords: biotechnology; corporations, life science; pharmacy

Otrzymano: 13 stycznia 2018

Received: 13 January 2018

Zaakceptowano: 21 maja 2018

Accepted: 21 May 2018

\section{Sugerowana cytacja / Suggested citation:}

Boguś, M., Dorocki, S. (2018). Międzynarodowe korporacje biotechnologiczne i farmaceutyczne na świecie. Prace Komisji Geografii Przemysłu Polskiego Towarzystwa Geograficznego, 32(2), 129-141. https://doi. org/10.24917/20801653.322.8

\section{WSTĘP}

Współcześnie powszechnie przyjmuje się, że rozwój ekonomiczny i społeczny krajów pozostaje $\mathrm{w}$ ścisłym związku z rozwojem innowacji i postępem technologicznym na ich terytorium. Innowacyjność i związana z nią konkurencyjność gospodarki jednostek terytorialnych różnego szczebla zależą głównie od poziomu kapitału ludzkiego. Głównym czynnikiem rozwoju przemysłu i usług nowych technologii jest zatem wysoko wykwalifikowana kadra specjalistów, tzw. klasa kreatywna, a także rodzaj kreowanej przez nią działalności naukowo-badawczej (Baum, Silverman, 2004; Dorocki, Boguś, Jastrzębski, 2014).

Po okresie boomu technologii informacyjnej przemysł life science (w tym biotechnologiczny i farmaceutyczny) uznawany jest za jeden z najważniejszych i najszybciej rozwijających się sektorów gospodarki zaawansowanych technologii. Stanowi on zatem ważny czynnik rozwoju społeczno-gospodarczego i kształtowania się gospodarki opartej na wiedzy. Przemysł ten uznawany jest za jeden z najbardziej innowacyjnych, generuje postęp nauk podstawowych, a także poprawia w znaczący sposób jakość życia (Dorocki, Jastrzębski, 2012).

Korporacje biotechnologiczne i farmaceutyczne są zlokalizowane głównie w pobliżu światowej klasy uczelni wyższych, zapewniającym im dostęp do wysoko wykwalifikowanej kadry specjalistów i infrastruktury badawczej (Dorocki, Borowiec, Boguś, 2013). Ich przestrzenna koncentracja jest wynikiem ścisłych powiązań pomiędzy podmiotami gospodarki i nauki. Korporacje biotechnologiczne i farmaceutyczne narażone są na duże ryzyko inwestycyjne, co wynika z szybkich zmian technologicznych oraz długiego procesu wdrażania produktów i usług. Rozwój tego przemysłu w dużym stopniu zależy też od czynników: ekonomicznych, społecznych (kulturowych), politycznych, ekologicznych i etycznych. Istotne są postawy społeczne i polityka władz, zwłaszcza w przypadku działań związanych ze stosowaniem modyfikacji genetycznych lub innych „wrażliwych moralnie" działań naukowych. Komercjalizacja biotechnologii wymaga zazwyczaj długich terminów realizacji, co ma związek z trudnościami związanymi z pozyskaniem kapitału na inwestycje o wysokim ryzyku. Dlatego kluczowe stają się regulacje prawne i ochrona własności intelektualnej, a co za tym idzie - zgłoszenia patentowe. 
W świetle przedstawionych przesłanek przedmiotem artykułu są transnarodowe korporacje biotechnologiczne i farmaceutyczne wyróżnione spośród 2000 największych korporacji różnych sektorów gospodarczych. Głównym celem artykułu jest określenie tendencji korporacji biotechnologicznych i farmaceutycznych na tle innych największych korporacji światowych oraz dynamiki przemian, jakie zachodziły w ich układzie przestrzennym i w ich potencjale ekonomicznym w latach 2006-2016.

Do realizacji przedmiotu i celu badań wykorzystano zbiorowe raporty publikowane przez „Forbes” - The Global 2000 - zawierające informacje na temat 2 tys. największych korporacji: ich klasyfikację według rodzaju działalności gospodarczej, siedzibę ich zarządów, wartość rynkową, wartość sprzedaży, wartość aktywów, wartość zysków. Przeprowadzone badania obejmują lata 2006-2016.

W badaniach wykorzystano wskaźnik potencjału ekonomicznego opracowany na podstawie wartości standaryzowanych wyników finansowych korporacji dla poszczególnych działów gospodarczych. Szczegółowe opracowanie wskaźnika zostało przedstawione w licznych opracowaniach (Raźniak, Dorocki, Winiarczyk-Raźniak, 2015; Raźniak, Dorocki, Winiarczyk-Raźniak, 2017).

\section{PRZEMYSŁ BIOTECHNOLOGICZNY I FARMACEUTYCZNY NA ŚWIECIE}

Biotechnologia przemysłowa jako interdyscyplinarna dziedzina nauki i techniki, oferująca bezpośrednie i potencjalne możliwości wspierania wzrostu gospodarczego, zatrudnienia i konkurencyjności, nie jest łatwa do zdefiniowania. Termin biotechnologia został użyty pierwszy raz w 1919 roku przez węgierskiego agronoma Karla Ereky'ego w odniesieniu do produkcji roślinnej. Współcześnie biotechnologia określana jest jako „zastosowanie procesów technologicznych, które wykorzystując organizmy żywe lub ich składniki, wytwarzają lub modyfikują produkty o określonym zastosowaniu" (Organizacja Narodów Zjednoczonych ds. Handlu i Rozwoju, UNCTAD), „zastosowanie metod naukowych i inżynieryjnych do obróbki materiałów czynnikami biologicznymi w celu pozyskania dóbr i usług" (Organisation for Economic Co-operation and Development, OECD) lub „integracja nauk przyrodniczych i inżynieryjnych w celu zastosowania komórek lub ich części oraz molekularnych analogów w celu pozyskania produktów i usług" (Europejska Federacja Biotechnologów). W opracowaniu przyjęto, że biotechnologia to zastosowanie procesów technologicznych, które - wykorzystując organizmy żywe lub składniki - wytwarzają lub modyfikują produkty o określonym zastosowaniu, a zatem jest interdyscyplinarną nauką, integrującą ze sobą nauki przyrodnicze i technologiczne. Zgodnie z klasyfikacją OECD, można wyróżnić umowne działy biotechnologii, określane kolorami: zielonym - dział dotyczący rolnictwa, czerwonym - stosowanym w ochronie zdrowia, i białym - dział wykorzystujący systemy biologiczne w produkcji przemysłowej i ochronie środowiska. Według innego podziału można wyróżnić biotechnologię tradycyjną - wykorzystującą naturalne enzymy lub organizmy, które nie zawierają obcego materiału genetycznego, oraz nowoczesną - stosującą zmodyfikowane genetycznie organizmy, enzymy i białka.

Przemysł farmaceutyczny definiowany jest jako wszelka działalność gospodarcza zaangażowana w badania, rozwój, produkcję i marketing środków stosowanych w celach medycznych i profilaktycznych u ludzi lub zwierząt. Do celów statystycznych, zarówno w Europie, jak i w USA, klasyfikuje się wszystkie leki produkowane w ramach branży farmaceutycznej, w tym także produkty opracowane $\mathrm{z}$ wykorzystaniem 
biotechnologii. Głównymi produktami przemysłu farmaceutycznego są zatem leki i środki biologiczne, które są substancjami przeznaczonymi do stosowania w diagnostyce, leczeniu i łagodzeniu chorób lub zapobieganiu im. Współcześnie przemysł farmaceutyczny nastawiony jest głównie na produkcję leków stosowanych w leczeniu raka, chorób związanych z układem krążenia, układu oddechowego, układu pokarmowego, cukrzycy, nadciśnienia, zaburzeń umysłowych i odpornościowych, np. HIV (Dorocki, 2014).

Uznać zatem należy, że przemysły biotechnologiczny i farmaceutyczny z wielu powodów trzeba analizować łącznie. W obu przypadkach jednym z głównych produktów są leki lub środki przeznaczone do ochrony zdrowia, a w procesie produkcji są wykorzystywane podobne technologie. Zarówno przemysł biotechnologiczny, jak i farmaceutyczny współuczestniczą w rozwoju nanotechnologii, która uznawana jest za najbardziej innowacyjną gałąź przemysłu (Dorocki, Kula, 2015).

W rankingu The Global 2000 w 2016 roku uwzględniono 2 tys. największych korporacji, które przyporządkowano do 11 różnych sektorów. Firmy z branży biotechnologicznej i farmaceutycznej zaklasyfikowano do sektora: opieka zdrowotna; były to 63 korporacje, czyli 3,15\% ogółu firm w rankingu.

W przestrzeni światowej, w wyniku nasilającego się procesu koncentracji kapitału, korporacje odznaczają się coraz większym potencjałem ekonomicznym, który często przewyższa potencjał gospodarczy wielu krajów (Zioło, 2006; 2008; Pugatch, Torstensson, Chu, 2012).

Poszczególne branże charakteryzowały się zróżnicowanym potencjałem ekonomicznym, przejawiającym się w: wartości sprzedaży (sales), wartości zysku (profits), wartości aktywów (assets) i wartości rynkowej (market value). W latach 2006-2016 korporacje biotechnologiczne i farmaceutyczne odznaczały się znaczną dynamiką potencjału ekonomicznego. Łączna wartość sprzedaży korporacji biotechnologicznych i farmaceutycznych (B\&F) zwiększyła się w tym okresie z 648,14 mld dol. do 1211,65 mld dol., czyli o187\% (ryc. 1 i 2). Wartość zysku zaznaczyła wzrost podobnego rzędu, z 73,88 mld dol. do 136,52 mld dol., czyli o 185\%. Również wartość rynkowa firm B\&F wzrosła ze 1662,34 mld dol. do 3022,90 mld dol., czyli o 182\%. W przypadku wartości rynkowej można zauważyć drobny spadek w latach 2008-2011, co może mieć związek z kryzysem światowym. Jednocześnie aktywa zwiększyły swoją wartość z 820 mld dol. do 1853,60 mld dol., czyli aż o 226\% (ryc. 1). Porównywalnie średnia wartość korporacji pozostałych sektorów wzrosła o 78,7\%.

W latach 2006-2016 można zauważyć zmiany udziału korporacji biotechnologicznych i farmaceutycznych w strukturze największych korporacji światowych. W badanym okresie nastąpił wzrost udziału korporacji biotechnologicznych w rankingu „Forbesa”, przy spadku liczby korporacji farmaceutycznych. Może być to spowodowane większą innowacyjnością oraz dochodowością biotechnologii (również wykorzystywanej w produktach farmaceutycznych). Wartość aktywów i sprzedaży utrzymywała się na podobnym poziomie, jednak nastąpił wzrost zysków i wartości rynkowej - bardziej dynamiczny w korporacjach biotechnologicznych i mniej dynamiczny w farmaceutycznych. Duży stopień zróżnicowania ekonomicznego korporacji biotechnologicznych i farmaceutycznych potwierdza wykres wartości miernika potencjału ekonomicznego, który został obliczony na postawie ustandaryzowanych wskaźników wyników finansowych (wartości sprzedaży, zysku, aktywów i wartości rynkowej) (Raźniak, Dorocki, Winiarczyk-Raźniak, 2017) (ryc. 2 i 3). 
Ryc. 1. Zmiany wartości potencjału ekonomicznego i dynamika zmian potencjału ekonomicznego korporacji biotechnologicznych i farmakologicznych w latach 2006-2016

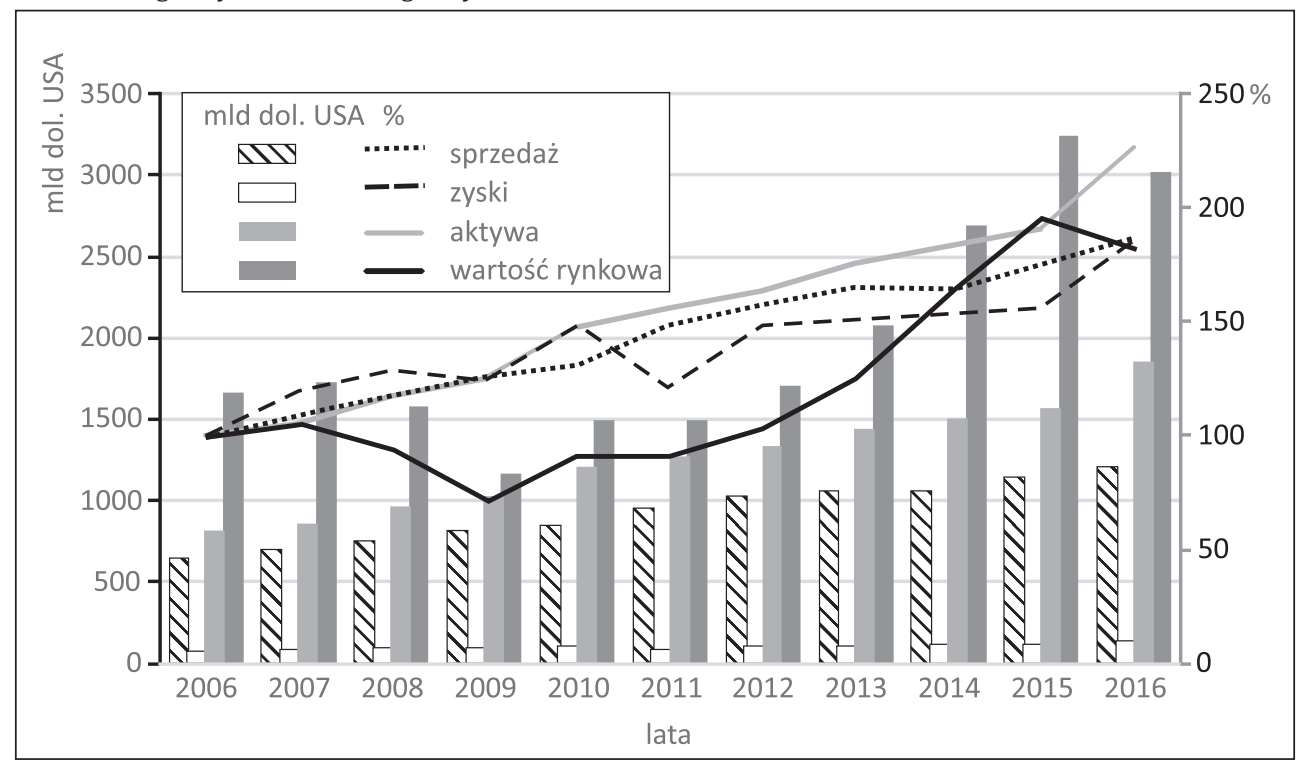

Źródło: opracowanie własne na podstawie Forbes (2018)

Ryc. 2. Zmiany udziału korporacji biotechnologicznych i farmaceutycznych w strukturze największych korporacji światowych wg rodzaju działalności w latach 2006-2016

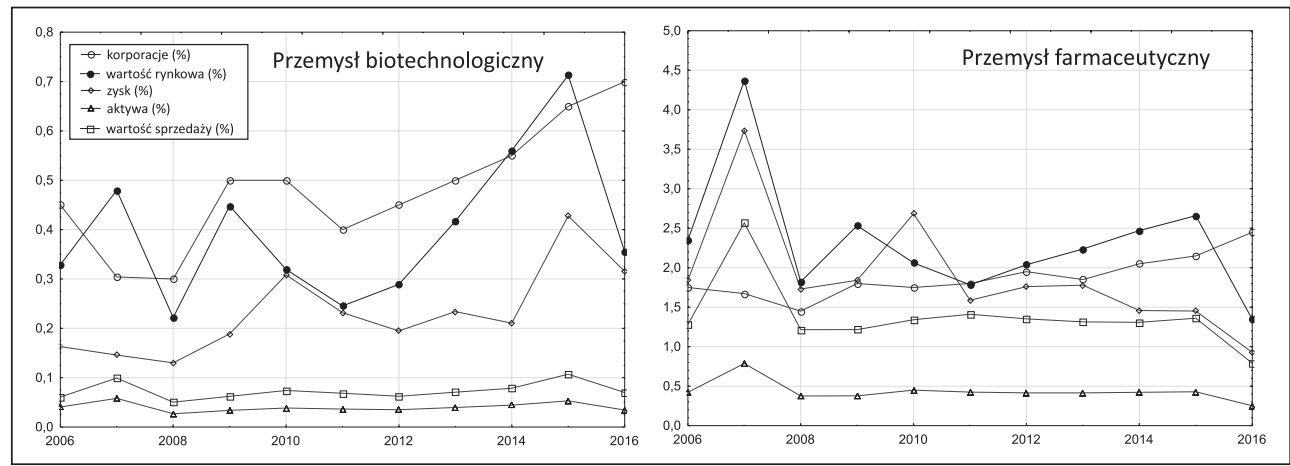

Źródło: opracowanie własne na podstawie Forbes (2018)

W latach 2006-2016 można zauważyć zmiany udziału korporacji biotechnologicznych i farmaceutycznych w strukturze największych korporacji światowych. W badanym okresie nastąpił wzrost udziału korporacji biotechnologicznych w rankingu „Forbesa", przy spadku liczby korporacji farmaceutycznych. Może być to spowodowane większą innowacyjnością oraz dochodowością biotechnologii (również wykorzystywanej w produktach farmaceutycznych). Wartość aktywów i sprzedaży utrzymywała się na podobnym poziomie, jednak nastąpił wzrost zysków i wartości rynkowej - bardziej dynamiczny w korporacjach biotechnologicznych i mniej dynamiczny w farmaceutycznych. Duży stopień zróżnicowania ekonomicznego korporacji biotechnologicznych i farmaceutycznych potwierdza wykres wartości miernika potencjału ekonomicznego, 
Ryc. 3. Wartości wskaźnika syntetycznego wyników finansowych

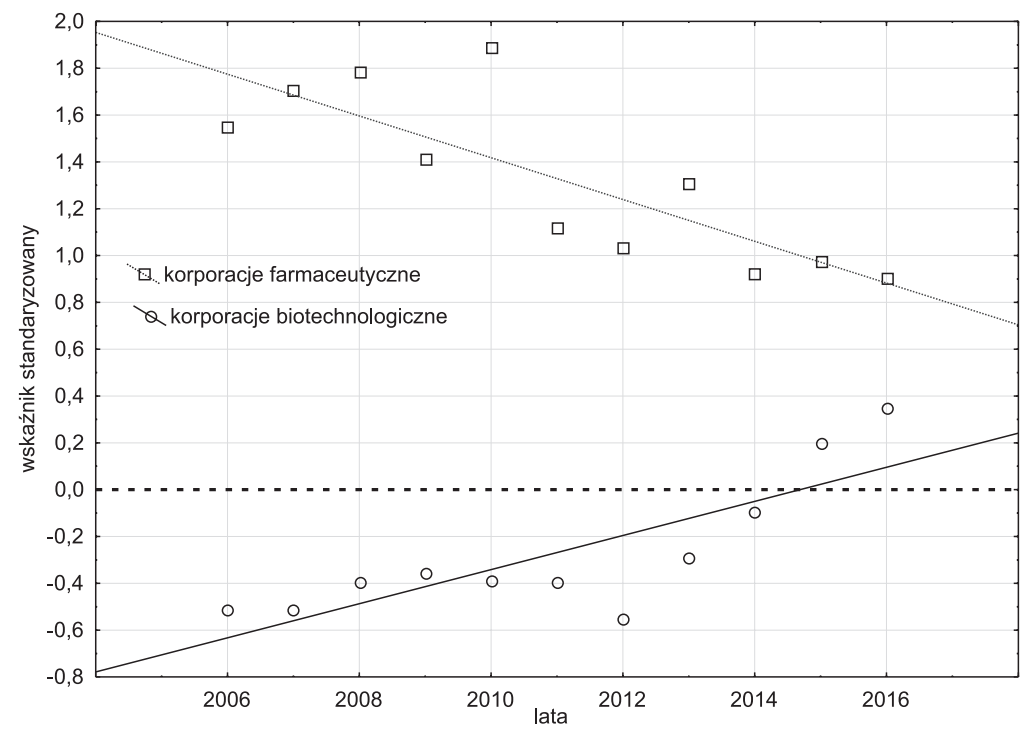

Źródło: opracowanie własne na podstawie Forbes (2018)

który został obliczony na postawie standaryzowanych wskaźników wyników finansowych (wartości sprzedaży, zysku, aktywów i wartości rynkowej) (Raźniak, Dorocki, Winiarczyk-Raźniak, 2017) (ryc. 2 i 3).

Szczególnie ważną rolę w organizowaniu światowej przestrzeni gospodarczej poprzez różnorodne systemy sieciowych powiązań odgrywają zarządy, pełniące funkcję centrów decyzyjnych w przypadku przepływu środków finansowych, prac badawczo-rozwojowych, nowych lokalizacji, rynków zbytu itp. W 2006 roku liczba korporacji biotechnologicznych i farmaceutycznych wynosiła 44, po czym w 2008 roku spadła do 35 (ryc. 4). Wzrost liczby korporacji postępował od 2009 roku, a w 2016 roku wynosił 63.

Dominującą rolę w strukturze krajów, na obszarze których korporacje biotechnologiczne i farmaceutyczne zlokalizowały swoje zarządy, odgrywały Stany Zjednoczone, w których w 2006 roku swoją siedzibę zarządu posiadało 20 korporacji, czyli 45\% ogółu korporacji tych branż (ryc. 5). W 2016 roku liczba zarządów w Stanach Zjednoczonych wzrosła do 24, jednak ich udział w ogóle spadł do 37\%. Drugie miejsce pod względem liczby zarządów omawianych korporacji zajmowała Japonia, w której w latach 2006-2016 ich liczba wahała się od ośmiu do 10 siedzib. Dalej plasowały się takie kraje Europy Zachodniej, jak Szwajcaria, w której liczba siedzib w omawianym okresie wahała się od dwóch do czterech, Irlandia, w której liczba siedzib wzrosła z jednej w 2006 roku do pięciu w 2016 roku, i Wielka Brytania - po dwie siedziby. We wszystkich wspomnianych krajach udział siedzib zarządów zmalał w ogóle korporacji biotechnologicznych i farmaceutycznych z wyjątkiem Irlandii, gdzie wzrósł z $2 \%$ do 9\% (ryc. 5).

Krajem, w którym nastąpił zauważalny wzrost siedzib korporacji B \& F, są Chiny. Pierwsza firma B \& F w Chinach pojawiła się w 2010 roku, natomiast pięć lat później 
Ryc. 4. Liczba korporacji biotechnologicznych i farmaceutycznych w latach 2006-2016

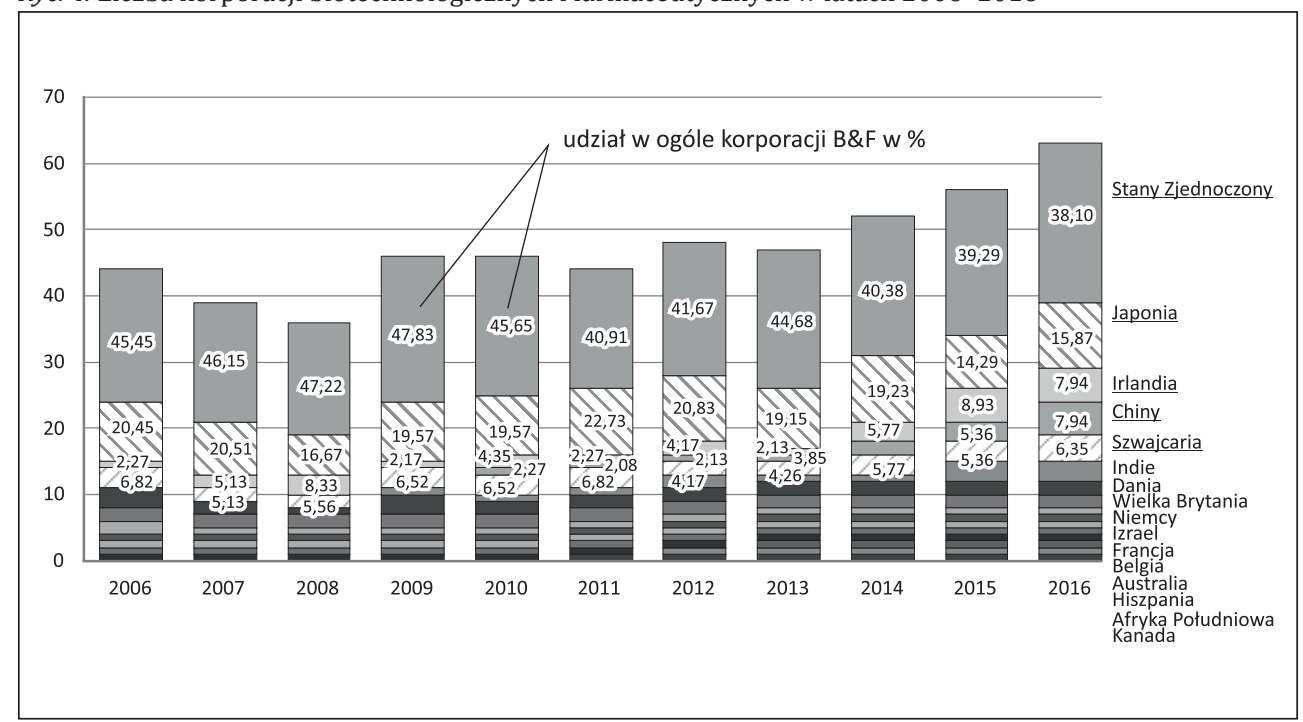

Źródło: opracowanie własne na podstawie Forbes (2018)

Ryc. 5. Zmiany wskaźnika syntetycznego finansów w latach 2006-2016 dla biotechnologii i farmacji

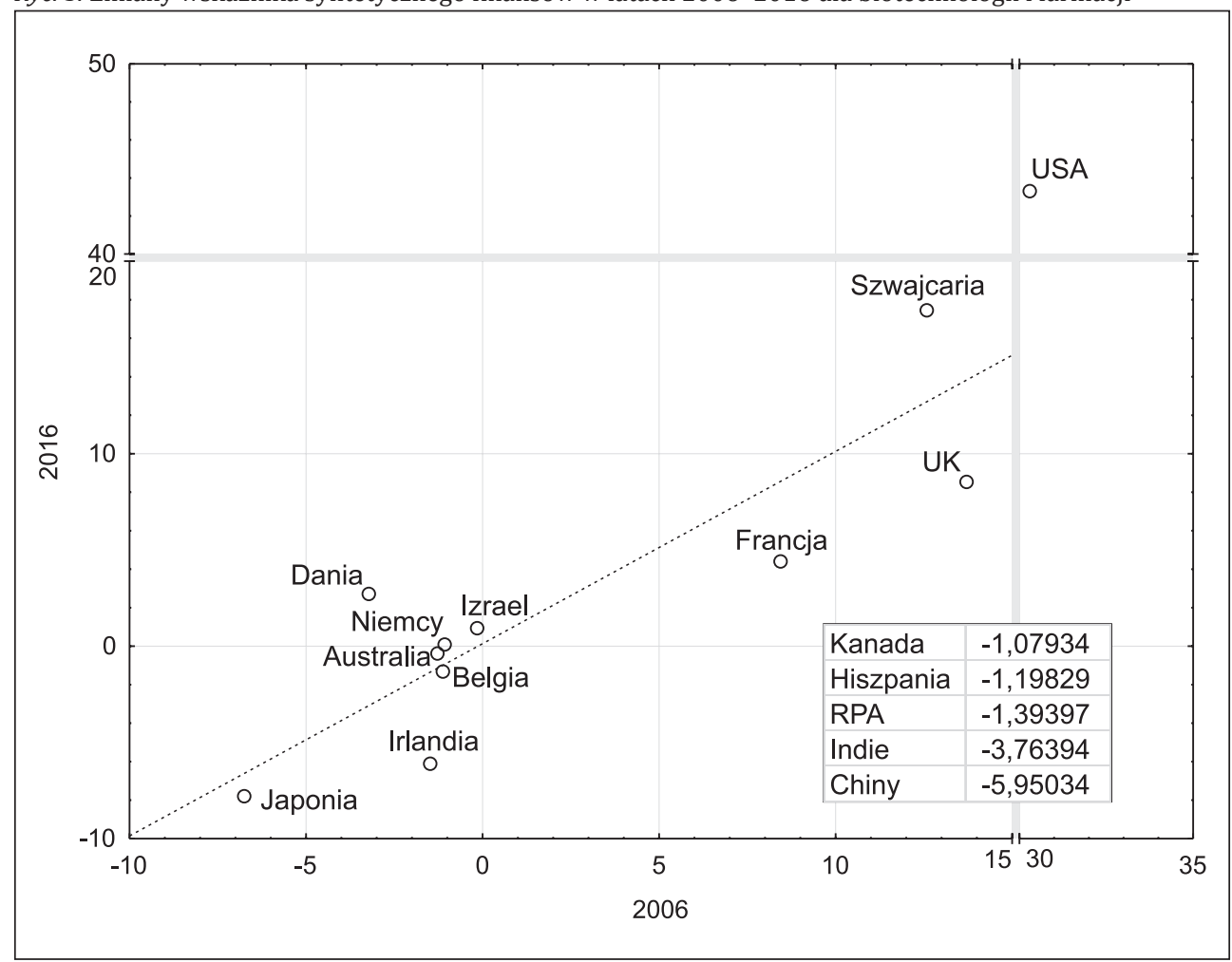

Źródło: opracowanie własne na podstawie Forbes (2018) 
było ich pięć. W 2016 roku Chiny skupiały 7,9\% ogółu firm B\&F, wyprzedzając Szwajcarię. W 2003 roku w Chinach utworzono National Bio-Industry High-Tech Industry Base, co stanowiło pierwszy krok do zapoczątkowania kolejnego etapu rozwoju państwa. Tym samym biotechnologia i farmacja zostały uznane za jedną z siedmiu strategicznych gałęzi rozwoju. Podobnie Indie w badanym okresie wykazały się dużym wzrostem liczby firm B\&F. Jest to wynikiem procesu delokalizacji przemysłu związanego z rozwojem gospodarczym regionów Azji i Ameryki Południowej (Dorocki, Boguś, 2014; Wójtowicz, Dorocki, 2014) oraz obniżenia kosztów produkcji (Hryniewicz, 2013; Dorocki, Brzegowy, 2014b). Dodatkowym czynnikiem jest prorozwojowa polityka Chin, która jest możliwa dzięki zgromadzonemu kapitałowi i rozwijanej infrastrukturze (Krupa, 2011; Koszek, 2017). Ważnym elementem są również uwarunkowania prawne, które są bardzo zróżnicowane w poszczególnych krajach (Dorocki, Brzegowy, 2014a). W wielu przypadkach wejście firm na rynek zagraniczny jest łatwiejsze poprzez stworzenie firm typu joint venture, co również może wpłynąć na lokalizacje siedzib korporacji (Xia, Gautam 2015; Li, Xie, 2016).

Na wykresie zmian standaryzowanego wskaźnika wyników finansowych według krajów w latach 2006-2016 można zauważyć dwa okresy: od 2006 do 2012 roku, kiedy wskaźnik niewiele się zmieniał, i po 2012 roku, kiedy dynamicznie zaczął wzrastać we wszystkich korporacjach, a przede wszystkim w tych zlokalizowanych w Stanach Zjednoczonych (ryc. 5). Było to związane z poprawą sytuacji ekonomicznej po kryzysie światowym.

Pomimo że w badanym okresie zauważalny był wzrost liczby korporacji B\&F w krajach rozwijających się, to jednak - po przeanalizowaniu potencjału tych korporacji - niezaprzeczalnym liderem pozostają Stany Zjednoczone Ameryki Północnej, które w badanym okresie zwiększyły swój potencjał finansowy. Na drugim miejscu pozostaje Szwajcaria, która w analizowanej dekadzie również odnotowała wzrost wskaźnika potencjału. W przypadku innych krajów o wysokim potencjale, czyli Wielkiej Brytanii i Francji, zauważany jest spadek potencjału finansowego w stosunku do innych firm. Spadek odnotowała również Japonia i Irlandia, a wzrost - firmy w Danii. Kraje, w których korporacje na liście „Forbesa” pojawiły się po 2006 roku, posiadają wszystkie ujemne wartości wskaźnika potencjału. Najniższy jest on w Chinach i Indiach. Dowodzi to, że firmy, które zlokalizowane są w tych krajach, posiadają jednak niski potencjał ekonomiczny.

Pośród 10 najlepszych korporacji omawianych branż można zauważyć wyraźny wzrost między 2006 a 2016 rokiem. Zarówno w 2006, jak i w 2016 roku dominowały korporacje amerykańskie, jednak w 2016 roku w ścisłej czołówce pojawiły się korporacje zlokalizowane w Chinach i Japonii. Regiony przodujące pod względem rozwoju biotechnologii i farmacji to Nowy Jork, lider w dziedzinie nauk przyrodniczych i life science, jednak współcześnie wykazujący opóźnienie w stosunku do Kalifornii, zwłaszcza w przypadku liczby zatrudnienia i przyciągania inwestycji kapitałowych (Dorocki, Raźniak, Winiarczyk-Raźniak, Boguś, 2017).

Czynnikami hamującymi rozwój omawianego przemysłu w Nowym Jorku są głównie brak odpowiednich i niedrogich przestrzeni laboratoryjnych oraz deficyt wykwalifikowanego sektora średniego. Największe korporacje należące do przemysłu life science to: Big Pharma, Bayer, Merc, Novartis czy Pfitzer. Bazylea ma długą tradycję działalności w przemyśle chemicznym i farmaceutycznym, czemu sprzyja położenie w centrum Europy i bliskość Renu. W ostatnich latach przekształciła się ona w klaster nauk przyrodniczych opartych na wiedzy. Obok dwóch wiodących firm farmaceutycznych 
Novartis i Hoffmann-La Roche obszar Bazylei jest też bazą oddziałów pokrewnych, np. Syngenta (agrobiznes), Ciba i Clariant (przemysł chemiczny) czy firm medycznych, takich jak Straumann i Synthes, a także Huntsman Advanced Materials, BAFS, Bayer Consumer Care (ryc. 6). Pojawienie się znaczących korporacji biotechnologicznych i farmaceutycznych lub przenoszenie ich do Azji (Chiny, Indie) jest spowodowane głównie mniejszymi kosztami produkcji na tamtejszych rynkach i ich otwartością. Co więcej, niektóre państwa, aby wyrazić zgodę na pojawienie się danych leków na ich rynku, muszą udzielić zezwolenia na przeprowadzenie badań na ich terytorium.

Firmy azjatyckie charakteryzuje duża alokacja kapitału (infrastruktura produkcyjna), natomiast bardzo małe wyniki sprzedaży. Niemniej jednak, wraz ze wzrostem rozwoju gospodarczego, ich sytuacja regularnie ulega zmianie i przewiduje się, że wkrótce będą to największe rynki zbytu. Na zachodzie Europy przemysł spotyka się z licznymi

Ryc. 6. Wyniki finansowe korporacji według miast w latach 2006 i 2016

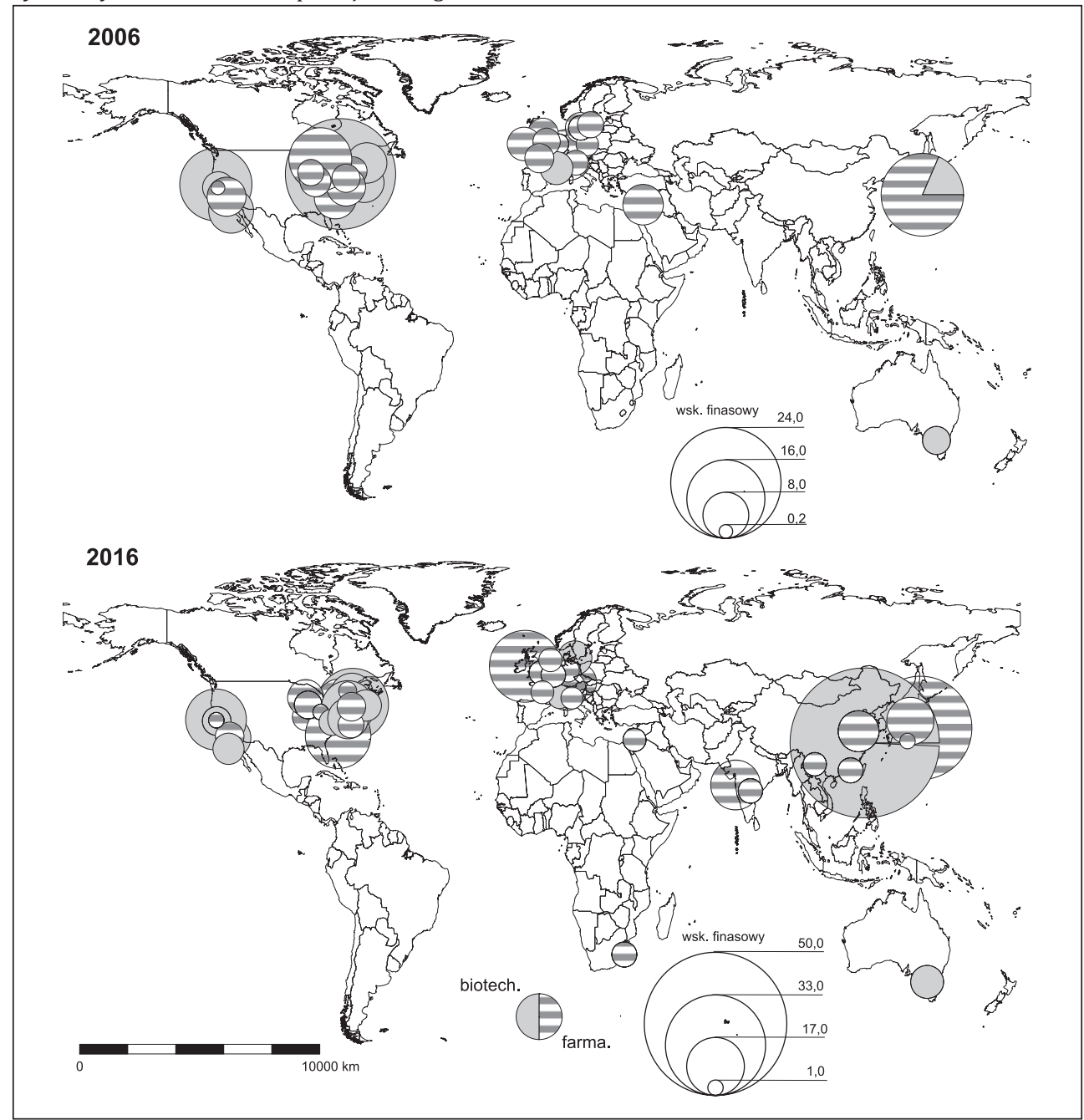

Źródło: opracowanie własne na podstawie Forbes (2018) 
ograniczeniami prawnymi badań, np. genetycznych. Korporacje europejskie działają bardziej zachowawczo w porównaniu z amerykańskimi, nastawionymi na duże ryzyko. Potwierdza to tabela z 10 największymi korporacjami B\&F spośród listy „Forbesa” (tab. 1). Podczas gdy w 2006 roku były to głównie firmy zlokalizowane w USA, to już w 2016 roku na pierwszym miejscu znalazły się Chiny, a na drugim Japonia. Wydaje się, że jest to zapowiedź przestrzennej zmiany centrów gospodarczych z zachodu na wschód.

Tab. 1. Wyniki finansowe 10 najlepszych korporacji w latach 2006 i 2016

\begin{tabular}{|c|c|c|c|c|c|}
\hline \multicolumn{6}{|c|}{2006} \\
\hline Lp. & Korporacja & Kraj & Sektor & Miasto & $\begin{array}{l}\text { Wskaźnik } \\
\text { finansowy }\end{array}$ \\
\hline 1 & Celgene & USA & biotechnologiczny & Summit, New Jersey & 24,01 \\
\hline 2 & Gilead Sciences & USA & biotechnologiczny & Foster City, Kalifornia & 14,65 \\
\hline 3 & Amgen & USA & biotechnologiczny & Thousand Oaks, Kalifornia & 7,91 \\
\hline 4 & MedImmune & USA & farmaceutyczny & Gaithersburg, Maryland & 7,23 \\
\hline 5 & $\begin{array}{l}\text { Teva Pharmaceutical } \\
\text { Industries }\end{array}$ & Izrael & farmaceutyczny & Petach Tikwa & 6,83 \\
\hline 6 & Genzyme & USA & biotechnologiczny & Boston, Massachusetts & 6,79 \\
\hline 7 & Biogen Idec & USA & biotechnologiczny & Weston, Massachusetts & 6,66 \\
\hline 8 & Allergan & USA & farmaceutyczny & Irvine, Kalifornia & 6,45 \\
\hline 9 & Barr Pharmaceuticals & USA & farmaceutyczny & Montvale, New Jersey & 6,40 \\
\hline 10 & Forest Laboratories & USA & farmaceutyczny & Nowy Jork & 5,74 \\
\hline \multicolumn{6}{|c|}{2016} \\
\hline Lp. & Korporacja & Kraj & Sektor & Miasto & $\begin{array}{l}\text { Wskaźnik } \\
\text { finansowy }\end{array}$ \\
\hline 1 & $\begin{array}{l}\text { Shanghai RAAS Blood } \\
\text { Products }\end{array}$ & Chiny & biotechnologiczny & Szanghaj & 50,38 \\
\hline 2 & Ono Pharmaceutical & Japonia & farmaceutyczny & Osaka & 22,98 \\
\hline 3 & Vertex Pharmaceuticals & USA & biotechnologiczny & Cambridge, Massachusetts & 21,40 \\
\hline 4 & Incyte & USA & farmaceutyczny & Wilmington, Delaware & 19,11 \\
\hline 5 & BioMarin Pharmaceutical & USA & biotechnologiczny & San Rafael, Kalifornia & 17,33 \\
\hline 6 & Alexion Pharmaceuticals & USA & biotechnologiczny & Cheshire, Connecticut & 14,39 \\
\hline 7 & $\begin{array}{l}\text { Regeneron } \\
\text { Pharmaceuticals }\end{array}$ & USA & biotechnologiczny & Tarrytown, Nowy Jork & 10,61 \\
\hline 8 & Illumina & USA & biotechnologiczny & San Diego, Kalifornia & 9,93 \\
\hline 9 & Jiangsu Hengrui Medicine & Chiny & farmaceutyczny & Lianyungang & 9,82 \\
\hline 10 & Novo Nordisk & Dania & farmaceutyczny & Bagsværd & 9,77 \\
\hline
\end{tabular}

Źródło: opracowanie własne na podstawie Forbes (2018)

\section{PODSUMOWANIE}

Obecnie następuje wzrost znaczenia korporacji biotechnologicznych i farmaceutycznych wśród największych korporacji światowych. Szczególnie szybko rozwija się przemysł biotechnologiczny (w tym biotechnologia biała), co jest spowodowane starzeniem się społeczeństwa, chorobami cywilizacyjnymi i wzrostem gospodarczym w krajach rozwijających się. Jako główne rejony rozwoju biotechnologii i farmacji podaje się kraje rozwinięte, takie jak USA, kraje Europy Zachodniej czy Japonia. Można jednak zauważyć 
delokalizację przemysłu biotechnologicznego, zarówno pod względem produkcji i badań klinicznych, jak i poszukiwania nowych rynków oraz bardziej przyjaznych uwarunkowań prawnych - jako przykład można podać Chiny lub Indie. Konieczne do rozwoju biotechnologii są: infrastruktura B\&R, wysokiej jakości kapitał ludzki i czynniki infrastrukturalne ( $w$ tym etyczne i prawne).

Wydaje się właściwe, aby w dalszych badaniach podjąć szczegółową analizę rozwoju poszczególnych korporacji - zarówno w krajach rozwiniętych, jak i rozwijających się. Pozwoli to na bardziej szczegółowe określenie znaczenia poszczególnych czynników dla rozwoju przemysłu life sciences. Szczególnie interesujące jest określenie pozaekonomicznych czynników rozwoju. W przyszłości w wyniku globalizacji uwarunkowania te mogą stać się jednymi z najważniejszych elementów warunkujących rozwój przemysłu biotechnologicznego i farmaceutycznego.

\section{Literatura \\ References}

Baum, J.A.C., Silverman, B.S. (2004). Picking winners or building them? Alliance, intellectual, and human capital as selection criteria in venture financing and performance of biotechnology startups. Journal of Business Venturing, 19, 411-436.

Bednarski, W., Fiedurek, J. (red.) (2017). Podstawy biotechnologii przemysłowej. Warszawa: Wydawnictwo Naukowe PWN.

Dorocki, S. (2014). Contemporary Trends in the Development of the Pharmaceutical Industry in the World. Prace Komisji Geografii Przemysłu Polskiego Towarzystwa Geograficznego, 25, 108-131. DOI: $10.24917 / 1681$

Dorocki, S., Boguś, M. (2014). Regional Variety of Biotechnology Development in Asia. Procedia - Social and Behavioral Sciences, 120, 197-212. DOI: http://dx.doi.org/10.1016/j.sbspro.2014.02.097

Dorocki, S., Boguś, M., Jastrzębski, J.P. (2014). Rozwój biotechnologii w miastach wybranych krajów Unii Europejskiej. Studia Miejskie, 13, 107-119.

Dorocki, S., Borowiec, M., Boguś, M. (2013). Przestrzenne zróżnicowanie rozwoju przemysłu biotechnologicznego. Prace Komisji Geografii Przemysłu Polskiego Towarzystwa Geograficznego, 21, 94-120.

Dorocki, S., Brzegowy, P. (2014a). France's stand on genetically modified food and its reception in the EU. W: A. Bobko, K. Cynk (red.). Genetycznie modyfikowany organizm jako przedmiot oceny moralnej. Rzeszów: Wydawnictwo Uniwersytetu Rzeszowskiego, 217-226.

Dorocki, S., Brzegowy, P. (2014b). The maquiladora effect on the social and economic situation in Mexico in the era of globalization. W: M. Wójtowicz, A. Winiarczyk-Raźniak (red.). Environmental and socio-economic transformations in developing areas as the effectof globalization. Kraków: Wydawnictwo Naukowe Uniwersytetu Pedagogicznego, 93-110.

Dorocki, S., Jastrzębski, J.P. (2012). Regionalne zróżnicowanie rozwoju biotechnologii w Europie. Prace Komisji Geografii Przemysłu Polskiego Towarzystwa Geograficznego, 20, 67-94.

Dorocki, S., Kula, A. (2015). Przestrzenne zróżnicowanie rozwoju nanotechnologii w Europie. Prace Komisji Geografii Przemysłu Polskiego Towarzystwa Geograficznego, 29(1), 27-41. DOI: $10.24917 / 2703$

Dorocki, S., Raźniak, P., Winiarczyk-Raźniak, A., Boguś, M. (2017). The role of global citiesin creation of innovative industry sectors. Case study - life sciences sector. Innovation Management, Entrepreneurship and Sustainability (IMES 2017), 136-146.

Forbes (2018, 13 stycznia). Pozyskano z https://www.forbes.pl

Hryniewicz, J. (2013). Przemysł, gospodarka oparta na wiedzy i wspólna europejska polityka przemysłowa. Prace Komisji Geografii Przemysłu Polskiego Towarzystwa Geograficznego, 21, 31-46. DOI: 10.24917/1193 
Koszek, R. (2017). Przejęcia europejskich firm jako przykłady chińskich inwestycji zagranicznych. Prace Komisji Geografii Przemysłu Polskiego Towarzystwa Geograficznego, 31(4), 133147. DOI: $10.24917 / 20801653.314 .9$

Krupa, K. (2011). Ekonomiczne i technologiczne strefy rozwoju Chin (kwantyfikacja, stratyfikacja, metodyka). Prace Komisji Geografii Przemysłu Polskiego Towarzystwa Geograficznego, 17, 87-98. DOI: $10.24917 / 340$

Li, J., Xie, Z.(2016), Governance Structure and the Creation and Protection of Technological Competencies: International R\&D Joint Ventures in China. Management International Review, 56(1), 123-148, https://doi.org/10.1007/s11575-015-0268-1

Pugatch, M.P., Torstensson, D., Chu, R. (2012). Taking Stock: How Global Biotechnology Benefits from Intellectual Property Rights. Pugatch Consilium, Commissioned by the Biotechnology Industry Organization. Pozyskano z http://www.bio.org/../Pugatch\%20Consilium\%20-\%20 Taking\%20Stock\%20Final\%20Report\%20(2).pdf

Raźniak, P., Dorocki, S., Winiarczyk-Raźniak, A. (2015). Ranga miasta w świetle syntetycznego wskaźnika stabilności gospodarczej. Studia Miejskie, 18, 119-130.

Raźniak, P., Dorocki, S., Winiarczyk-Raźniak, A. (2017). Permanence of the economic potential of cities based on sector development. Chinese Geographical Science, 27(1), 123-136. DOI: 10.1007/s11769-017-0850-5

Wójtowicz, M., Dorocki, S. (2014). Regional differences in the development of the biotechnology industry in Latin America, with particular emphasis on Brazil and Mexico. W: M. Wójtowicz, A. Winiarczyk-Raźniak (red.). Environmental and socio-economic transformations in developing areas as the effect of globalization. Kraków: Wydawnictwo Naukowe Uniwersytetu Pedagogicznego, 111-135.

Xia, Ch., Gautam, A. (2015). Biopharma CRO industry in China: landscape and opportunities. Drug Discovery Today, 20(7), 794-798, https://doi.org/10.1016/j.drudis.2015.02.007

Zioło, Z. (2006). Zróżnicowanie światowej przestrzeni przemysłowej w świetle koncentracji siedzib zarządów wiodących korporacji. Prace Komisji Geografii Przemysłu Polskiego Towarzystwa Geograficznego, 8, 9-26.

Zioło, Z. (2008). Procesy transformacji przemysłowych układów przestrzennych na tle zmieniającego się otoczenia. Prace Komisji Geografii Przemysłu Polskiego Towarzystwa Geograficznego, 10, 11-22.

Marta Boguś, mgr, absolwentka pięcioletnich nauczycielskich studiów magisterskich na kierunku geografia, ze specjalnością przedsiębiorczość i gospodarka przestrzenna, oraz czteroletnich stacjonarnych studiów doktoranckich w Instytucie Geografii Uniwersytetu Pedagogicznego w Krakowie. Zainteresowania badawcze skupiają się głównie wokół problematyki korporacji ponadnarodowych, w tym korporacji informatycznych, a przede wszystkim biotechnologicznych.

Marta Boguś, M.Sc., graduated from Pedagogical University of Cracow, M.Sc. in Geography with a specialization Entrepreneurship and Spatial Management. She graduated from PhD studies in Pedagogical University of Cracow, Institute of Geography. Her scientific research are focused on international corporations such as IT corporations and above all biotechnological ones.

\section{Adres/address:}

$$
\begin{aligned}
& \text { Uniwersytet Pedagogiczny w Krakowie } \\
& \text { Instytut Geografii } \\
& \text { Zakład Geografii Społeczno-Ekonomicznej } \\
& \text { ul. Podchorążych 2, 30-084 Kraków, Polska } \\
& \text { e-mail: mbogus@up.krakow.pl }
\end{aligned}
$$

Sławomir Dorocki, dr, absolwent studiów z zakresu geografii społeczno-ekonomicznej Uniwersytetu Pedagogicznego w Krakowie, doktor nauk humanistycznych w dyscyplinie historia (Instytut Europeistyki, Uniwersytet Jagielloński). Adiunkt w Instytucie Geografii Uniwersytetu Pedagogicznego w Krakowie. Zainteresowania badawcze skupiają się wokół problematyki regionów i procesów regionalizacji społeczno-gospodarczej, ze szczególnym uwzględnieniem zróżnicowania przestrzeni europejskiej oraz procesów integracji europejskiej i uwarunkowań historycznych oraz zastosowania metod komputerowych i statystycznych w badaniach nad zróżnicowaniem przestrzeni. 
Sławomir Dorocki, Ph.D., Department of Entrepreneurship and Spatial Management, Institute of Geography, Pedagogical University of Cracow. Sławomir Dorocki, graduated from Pedagogical University of Cracow, MA degree in geography, Ph.D. in history (Institute of European Studies of the Jagiellonian University). Adiunkt (assoc. professor) at Pedagogical University of Cracow, Institute of Geography. His research interests are tied with regional problems and processes of socio-economic regionalization, with particular emphasis on the diversity of Europe, processes of European integration, historical conditions and application computer and statistical methods in the study of diversity of space.

\section{Adres/address:}

Uniwersytet Pedagogiczny w Krakowie

Instytut Geografii

Zakład Przedsiębiorczości i Gospodarki Przestrzennej

ul. Podchorążych 2, 30-084 Kraków, Polska

e-mail: sdorocki@up.krakow.pl 